Milica Jovanović

Innovation Center, University of Nis
SCIENTIFIC REVIEW ARTICLE

doi:10.5937/ekonomika1904087J

Received: September 09. 2019.

Accepted: October 14. 2019.

\title{
THE POLITICAL BEHAVIOR OF MANAGERS AND EMPLOYERS AS AN INSTRUMENT FOR ADVANCING CAREER - INFLUENCE AND FACTORS ON INDIVIDUAL AND ORGANIZATIONAL EFFECTIVENESS
}

\begin{abstract}
The concept of political behavior within organizations is a topic of research in a lot of fields, such as management, human resources, psychology, sociology. It is dealing with a type of informal behavior within an organization, meaning that such activities are not approved formally by the organization itself, but the individuals would still often undertake them in order to achieve personal interests or protect the interests of others. The main goal of this paper is to point out to the reasons of political behavior within a company, as well as the consequences of such behavior. A crucial importance will be given to the importance of political skills for increasing the control and power and influencing others to behave in accord with the goals of individuals or groups within such companies. Such skills have a very important role in terms of organizational changes, leadership and understanding organizational politics.
\end{abstract}

Key words: political behavior, political skills, factors, effects

JEL classification: L29

\section{ПОЛИТИЧКО ПОНАШАҢЕ МЕНАҢЕРА И ЗАПОСЛЕНИХ КАО ИНСТРУМЕНТ НАПРЕДОВАЫА У КАРИЈЕРИ - ФАКТОРИ И УТИЦАЈ НА ИНДИВИДУАЛНУ И ОРГАНИЗАЦИОНУ ЕФЕКТИВНОСТ}

\begin{abstract}
Апстракт
Концепт политичког понашаға у организацијама, предмет је изучаваюа различитих дисииплина, као ито суменаимент, лудски ресурси, психологија, соицологија. Реч је о неформалном облику понашана у организацији, ито подразумева да ове активности нису званично одобрене од стране организације, али их појединии предузимају како би остварили сопствене или заштитили нечије интересе. Циль рада је да се укаже на разлоге политичког понашана у предузећу као и последице оваквог понашана. Посебно ће се указати на значај политичких вештина за повећане контроле и моћи и утииај на друге да се понашају у складу са иильевима појединаца или групе у предузећу. Ове вештине имају важну улогу у организационим променама, лидерству и разумевану организационе политике.
\end{abstract}

Кјучне речи: политичко понашате, политичке вечтине, фактори, ефекти

${ }^{1}$ jovanovicmilicaa90@gmail.com 


\section{Introduction}

The members of an organization use different tactics of political behavior as to fulfill certain goals in their careers. Such tactics are called influence tactics. They deal with different methods of working within an organization in order for someone to advance in their career, secure a better position within the organization, increase control, power and benefits. Such behavior does not necessarily need to impact the organization in a negative way. For this reason alone, there are literary talks about both positive (Mintzberg, 1977; Dix and Savickas, 1995; Ferris et al., 2007; Coopey \& Burgoyne, 2000; Kapoutsis \& Thanos, 2016) and negative sides (Kumar \& Rehana, 1989; Valle \& Witt, 2001; Sussman, 2002; Semmer, 2006; Chang, Rosen \& Levy, 2009; Olorunleke, 2015) of employees' behavior. In case such behavior secures better interests for the company as well as for the employees, such behavior has generally positive effects from the aspect of the organization as a whole. However, it is often the case when political tactics are used that the interests of certain members or groups are focused on, neglecting and working against the interests of the organization as a whole.

Political behavior is the reality of modern enterprises. Although, the certain factors influencing such behavior of the organization's employees can be debated. These factors can be individual, that is, related to the personal characteristics of employees, as well as organizational, or in relation to uncertainties in the functioning of the organization (Bauer \& Erdogan, 2016). With this we have in mind the system of performance assessment and the promotion of employees and, also, vaguely defined responsibilities of members in the functioning of the organization. Organizational politics and culture with a system of values and employee's beliefs play an important role in both stimulating and discouraging members to adopt such behavior.

The consequences of different aspects of political behavior of the employees can be monitored from both the individual and organizational aspect. Also, both positive and negative effects can be taken into consideration when it comes to the usage of different tactics of political behavior. Many researchers point out to the decrease in motivation of the employees, the incline of dedication to the organization (Chang, Rosen \& Levy, 2009) and increased stress (Semmer, 2006) and agitation at work as key consequences of excessive use of political behavior tactics within an organization. However, the positive effects cannot be disregarded, primarily when it comes to increase in earnings, promotion and other types of employee stimulation as key benefits from the individual aspect (Kumar \& Rehana, 1989; Kapoutsis \& Thanos, 2016). The enterprise itself can benefit as well, for by using such techniques there can be an increase of productivity of the employees, the increase of their dedication, finding new methods to compete with other members, which can influence the healthier competition inside the organization, which becomes an important factor of their efficiency at work.

The main goal of this paper is to explain the concept of political behavior in an enterprise and to emphasize the importance of these tactics for career advancement as well as effects from an organizational perspective. In addition, the aim is to analyze not only the positive aspects of this concept, but also the possible negative effects from both the individual and organizational level.

The first part of this paper explains the concept of political behavior in business and typology. The second part presents various aspects of political behavior in an 
organization. After that, the factors of political behavior are analyzed, while the last part gives the positive and negative consequences of the implementation of such tactics in the company.

\section{Conceptual determination of the political behavior concepts within the enterprise}

The approach to the organization as the political entity is not new, having in mind that March (1962) noticed in the year of 1962 "that the organizations are political coalitions within which decisions are made and goals set in the process of negotiation". Politics is involved in the business of every enterprise, having in mind that the enterprises being organizations need to adapt to the interests of numerous stakeholders. "Even $93 \%$ of the surveyed managers said that they believe that there is political behavior within their organizations, while $70 \%$ thinks that involvement in such behavior is required for the individual to become successful" (Gandz \& Murray, 1980). Namely, within the enterprise as an organization there are interests of different groups while the resources are often limited, making the employees resort to the various tactics of political behavior as to make their career goals easier and become more successful in general.

The concept of political behavior is the topic of research of different authors for more than three decades already. "Political behavior is either individual or group behavior which is informal, seemingly legitimate, usually destructive for the organization and, in technical sense, illegal, but unsanctioned neither by the formal authority, accepted ideology, nor confirmed expertise" (Mintzberg, 1977). "It represents the tactical influence of the employee who is led by the strategic goal, being both rational and conscious, leaning towards the fulfillment of his personal interests which are in accord or discord with the interests of others within an organization" (Valle \& Perrewe, 2000). "Political behavior within an organization can be defined as such activities which are not required within the frame of the organizational role of the individual, but they influence or attempt to influence the pros and cons of the organization" (Farrell \& Patterson, 1982). This means that such influences can be aligned with the interests of the other members of the organization or with the goals of the organization itself as well as with the values, but they can be opposite with them as well. That will primarily determine the influence of such behavior of the employees when it comes to the business of the organization. It allows the employees and managers to create an impression of fulfilling the standards that are highly valued by the enterprise, which directly influences the possibility of career advancements.

Political behavior is a term more narrow than the term organizational politics. Organizational politics allows the usage of resources at hand for the completion of required goals, in such conditions in which the interests of the members of the organization are conflicted. "Organizational politics has three levels - individual, group and organizational. Such politics is imposed by the organization, and not the individual, which differs greatly from the political behavior. This implies that the key difference between organizational politics and political behavior lies in the fact that the former derives from the organization and latter from the individual" (Jafariani, Mortazavi, Nazemi \& Bull, 2012). Organizational politics is determined by the organizational culture, that is, by the system of values and principles which are accepted within an organization and which leans towards directing 
the members in order to fulfill the organizational goals, while the political behavior is focused on the completion of personal goals and interests within a certain organization.

"The important characteristic of the political behavior is that it occurs within conditions of vaguely set goals in the organization, scarce resources, changeable environment and technology, unprogrammed decisions" (Miles, 1980). Within stable conditions of business, with clearly-defined organizational structure of the enterprise and innovative culture, the employees will be more dedicated to the organization and they will align their goals with the goals of the organization. This will demotivate their political behavior. However, political behavior has become conventional for the functioning of the contemporary enterprises, but not an exception. The probability of expressing the political behavior within organization increases with major disagreements when the goals of the organization are concerned, vaguely determined goals, different and conflicting ideas of the employees and interpersonal problems, as well as with the inadequate information.

The research shows that the political behavior is more closely connected with the employees holding higher positions within the enterprise and that it is less closely connected with the employees holding lower positions within the enterprise (Appelbaum \& Hughes, 1998, p. 85). This means that managers and employees working on higher hierarchical levels of the organization use their political skills more profanely in order to influence other members for the completion of certain benefits. Such behavior is especially important for influencing their subordinate colleagues to work in accordance with the interests of the organization, while at the same time for it not to seem like manipulative behavior. Besides that, they need to be skilled in motivating and understanding their employees.

Szoc (1999) indicates that both managers and employees would rather engage in political behavior when the procedures of decision-making and performance evaluation within the organization are complex and unclear and when the competition between the members within the organization is strong in terms of scarce resources of the organization. Contrary to this, in a stable and less complex environment, with a clear decision-making process and lesser presence of competitive behavior, excessive political behavior is highly unlikely.

Farrell and Petersen (1982) saw political behavior through three dimensions. Those dimensions point out to methods of ensuring that the employees have sufficient resources in order to influence the benefits within the organization, that is, the management tactics of available resources. Internal - External dimension includes the external dimension which deals with the usage of external resources for the purpose of achieving goals (spying, important information leaking, cooperation with people outside the organization) and the internal dimension or the usage of already available resources within the organization (cooperation with the employees, taking revenge, revolting, remonstrating). Horizontal - Vertical dimension deals with the political behavior that manifests between the subordinates and superiors, as well as in between colleagues on the same hierarchical level. Legitimate - Illegitimate dimension includes the legitimate dimension of political behavior, or, launching complaints about the superiors, disrespecting the decisions of the superiors, doing professional activities outside the boundaries of the enterprise and illegitimate political behavior, or, behavior which contradicts the politics and functions of the organization (breaking and sabotaging rules, revolting, disorder, snitching). 
Table 1: Typology of the political behavior within an organization

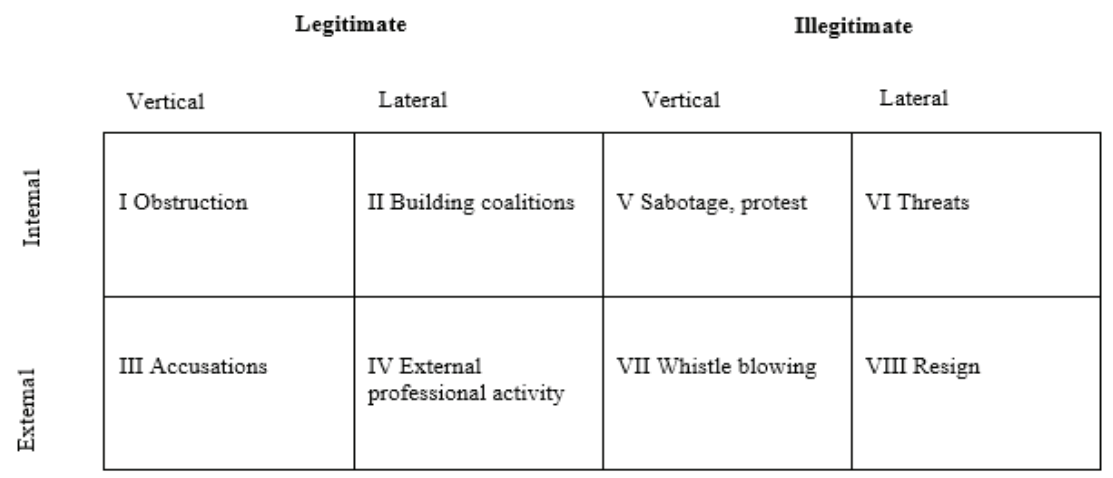

Source: According to Latif, A., Abideen, U. Z., Nazar, S. M., 2011

Based on the previously explained dimensions of the political behavior of the employees, a multidimensional review of the political situation became enabled, as it can be seen in Table 1. Field I is characteristic for the organizations with a broad range of rewards within the enterprise and with limited influence of the employees in the decisionmaking processes. Field II includes the employees on the same hierarchical levels who, by forming coalitions, can contribute to the goals of the enterprise. External vertical political behavior includes the accusations of the employees, but also the situations that can settle the disputes within the organization by discussion. The employees and managers can even use certain information or contacts outside of the organization which may help them in their fulfillment of goals within the organization. On the other hand, fields V, VI, VII and VIII include the illegitimate political behavior which can be sanctioned within the enterprise, and can also lead to getting fired.

Political skill is the key determinant of political behavior. "It represents the ability of effectively understanding other people at work and using such understanding to influence others towards fulfilling its own personal goals or those of the organization" (Ferris, Treadway, Kolodinsky et al., 2005). "Political skill allows individuals characterized by a high degree of understanding interactions to use such understanding to influence social results at the working environment" (Todd, Harris, Harris, \& Wheeler, 2009, p. 183). "Political skill is not the tactic of influence - political skill makes the tactic of influence effective. Having political skills increases managerial and organizational effectiveness" (Perrewe \& Nelson, 2004, p. 376).

This is about the ability of adapting the behavior of an individual to different and variable situations. Political skills increase the predictability within an organization, lower uncertainty and increase the control over events taking place within the organization. There is an understanding that individuals with developed political skills have larger selfconfidence and personal security at the workplace, having in mind that they achieve a higher degree of interpersonal control and also the control over activities happening in social interactions at work. Besides that, such people are more unburdened, stress is not present as much while they work and they can also possess manipulative skills. Without developed political skills, political behavior will not be as efficient. 
Picture 1: The relationship of political skills, organizational politics and organizational changes

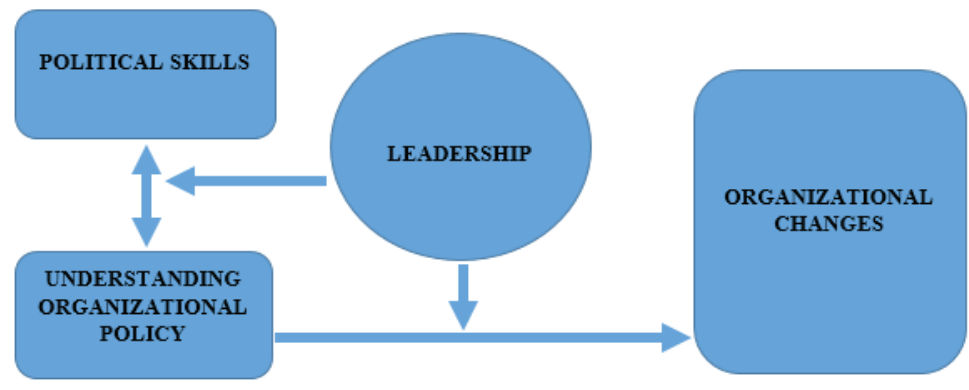

Source: According to Cheema, I. Q., Cheema, H. A., Ashraf, K., 2008, available at: http://www. regent.edu/acad/global/publications/sl_proceedings/2008/cheema-ashraf.pdf (retrieved 17.09.2016.)

Picture 1 shows that the leaders with developed political skills and who understand organizational politics are more capable to manage organizational changes in the effective way. Besides that, a close connection between political skills of the leaders and understanding the organizational politics of the enterprise is being highlighted. According to this model, the leaders with political skills could cope easier with the negative effects of the organizational politics, but also to use the positive effects for their benefit or for the benefit of the organization. They are especially successful in using that with the goal of promoting themselves within the organization. Such leaders have no aversion towards the changes in the enterprise, but they use such changes to advance their careers further. This is a key trait for all leaders in contemporary and innovative enterprises.

Understanding subordinates and their hidden intentions is especially important for leaders in the enterprise. Besides that, political behavior of the employees without developed political skills can be scorned by the other colleagues and superiors and be misunderstood for not acceptable behavior, or, a behavior that is not accord with widelyaccepted standards within an enterprise. Such employees and managers not only do not possess the ability to develop connections with other employees and using such connections in their workplace, but they are also characterized by having problems in communication and the inability to motivate others.

\section{Different aspects of political behavior of the employees}

In case political behavior is done by using legitimate means and goals, such behavior is legitimate; it can be developed and to positively influence the interactions between the members of the organization. Contrary to that, in case members of the organization use illegitimate means and goals, such behavior is illegitimate (Jafariani, Mortazavi, Nazemi \& Bull, 2012, p. 2991). This means that political behavior does not need to be dysfunctional on its own. Having in mind that the goals of political behavior can be both group and individual, and that they are both intertwined, there are some difficulties in determining whether the political behavior is legitimate or not. Such approach to the political behavior is shown in Picture 2. 
Picture 2: Types of behavior within the organization

Influence of goals

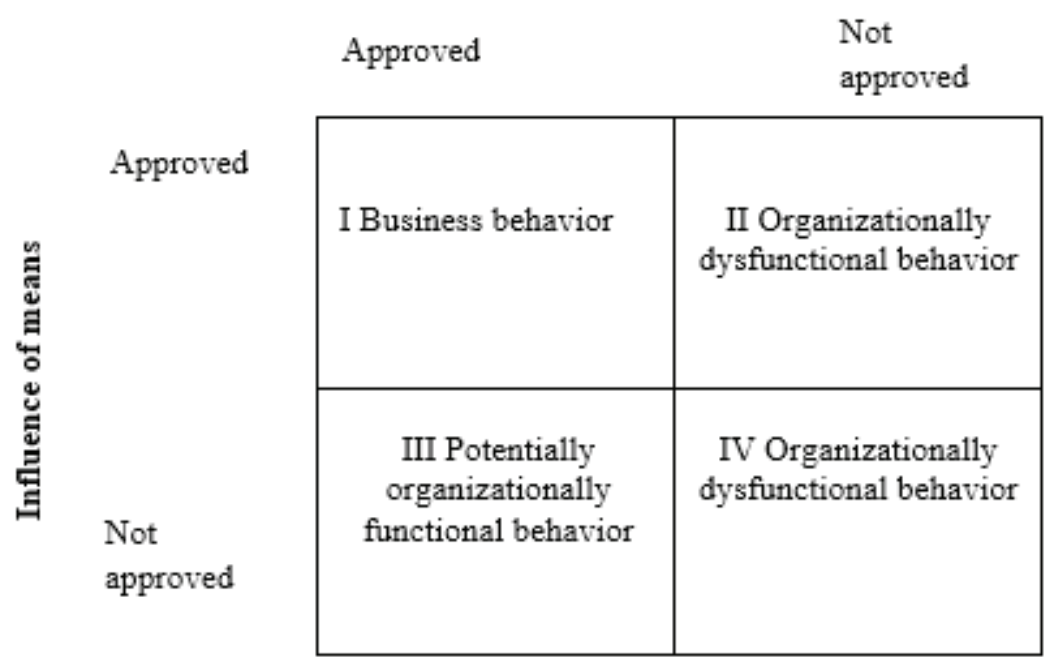

Source: According to Jafariani, H., Mortazavi, S., Nazemi, S. and Bull, P., 2012

Picture 2 points out that field I represents non-political behavior, or rather, represents business behavior, which is approved by the organization. Field II includes political behavior which is based around the abuse of power within the position in the enterprise in which the person is employed. Such behavior is dysfunctional with the aspect of the organization due to the fact that internal resources are used for the fulfillment of goals which are independent from the goals of the organization. Clearlydefined responsibilities, rules and principles could prevent this form of political behavior. Such behavior is included in the field IV as well because such behavior is opposing the goals of the organization, but also the resources used as well. This table points out that the political behavior is neither positive nor negative on its own. Mayes and Allen (1977) have also made this conclusion and they believe that both the goals and means, two very important criteria for classifying a behavior as legitimate or illegitimate ${ }^{2}$. Also, they conclude that legitimate political behavior within a specific culture is not necessarily legitimate in another. More precisely, the legitimacy of the political behavior is contextdependent. All of this points out to the complexity of the term political behavior.

"Political behavior is positive when it serves the vision and goals of the organization, develops teamwork and boosts self-confidence of the employers, while being ethically well-balanced" (Vigoda-Gadot \& Drory, 2006, p. 337). Vigoda-Gadot i Kapun (2005) think that "there is a set of positive outcomes of political behavior:

\footnotetext{
${ }^{2}$ The most common types of illegitimate behavior include talking behind the backs of other employees or spreading false information about them, accepting credit for other people's work, keeping important information for oneself or spreading false information, favoring of individuals, that is, the behavior that satisfies the personal interests of the individual and not those of the organization.
} 
career advancement, recognition and status, enhanced position and power, fulfillment of personal and organizational goals, successful realization of tasks at work, the feeling of control, success and accomplishment" (p.256). Political behavior is most commonly included in accomplishing such results, especially when one wants to achieve advanced within an organization or to get appraised by their associates. Some tactics can influence acquiring of new knowledge within the organization over different types of connecting and linking with the members of the organization, but also with the subjects outside of the organization.

Some authors, however, point out to the negative side of the political behavior. Curtis (2003) points out that "political behavior restricts information-sharing and communication within an organization, which is an important obstacle to organizational learning" (p.296). Various tactics of political behavior which allow the fulfillment of individual goals based on the possession of the important information can be used in order to keep the power, which is contrary to the interests of the organization. This is especially the case within organizations in which exists a low level of trust between their members, which may lead to their decrease in dedication. This way, the information are being manipulated with in order for someone to acquire personal gain or to acquire the gain of the group that person belongs to, but this does not necessarily mean that it goes against the interests of the enterprise itself. This means that political behavior can include both benefits and expenses.

In conditions of intensive competition within and enterprise in which resources are limited, political behavior is more common. Such behavior might "distort" the image of employees' performances at work, which points out to the negative side of the political behavior of the employees. This means that an unjust system of rewarding and stimulating the employees can be established. The leaders play an important role in preventing such situations. They should encourage teamwork and rewarding based on the real performances. That way, it will be shown that excessive political behavior will not be rewarded and that it can find disapproval among the others.

\section{Factors of political behavior}

The sources of political behavior are based on managerial, organizational, individual and group reasons (Akgemci \& Gok Gokce, 2015, p. 184). Managerial-organizational reasons include the relationship towards the unjust resource sharing or, in other words, affectionate behavior towards certain members of the organization who, by using their tactics of political behavior, adulate to their superiors or colleagues. In that regard, the employees could manage information, form close relationships with colleagues or superiors, connected with people outside of the organization, all in the purpose of using such contacts to achieve career success. Individual reasons include that some members of the organization have character traits which lean towards the political behavior. That way, they are trying to protect themselves from unacceptance by the managers and other employees, wish to progress their career in a short time period and try to convince others that they are important for the organization. Group reasons include separation of the strong organizational groups with which the individual avoids getting into conflict and the existence of informal relationships that are even far powerful than formal ones. The 
individual uses certain tactics in order to become a part of such groups or in order to gain their allegiance and trust.

In case the enterprise does business in an uncertain environment, in terms of organizational changes and strategic decision making, there are no objectivelydefined standards of performance, there is a branched-out hierarchical structure with the concentration of power in the highest administrative levels and non-developed social intelligence of the leader, there are great opportunities for expressing political behavior and manipulative efforts of employees and managers. Such conditions can be characterized as factors that encourage the expression of political skills in an enterprise.

Some authors make a difference between individual and organizational factors of political behavior. They include certain prerequisites for the manifestation of the political behavior on individual and organizational levels. The character of the individual or, rather, his/her characteristics, greatly influences whether they will engage in the political processes in the enterprise or not. We can classify the individual factors by the following:

- Political skills;

- Internal control locus;

- Investing in an organization;

- Expectations concerning success (Bauer \& Erdogan, 2016).

"Political skills are referred as the interpersonal style of people, including their ability to behave well towards others, self-monitor, and to change their reactions in accordance with the situation they are in and to boost reassurance and self-confidence" (Ferris et al., 2000). Research (Ferris, Fedor \& King, 1994; Kilduff \& Day, 1994) show that the individuals who have developed political skills are more effective in the workplace and they have a stronger influence on their ratings given to them by their supervisors concerning their performances. Individuals with the internal control locus believe that they can make a difference in the organizational results. Such people leave nothing to chance and they use different means to enhance the impression whenever their performance is concerned by the superiors. They believe that external factors have no impact on their personal results. Because of this, people with internal control locus are much more likely to engage in political behavior, believing that everything that revolves around them is in their hands alone. Research shows that such persons are more successful in perception of the political behavior in their environment (Valle \& Perrewe, 2000). The level of investment in the organization also affects political behavior. If investments in the organization of an individual are great, whether financial or emotional, they will become more and more motivated to engage in political behavior, because they are more interested in the fate of the organization than others are. Such individuals identify themselves with the organization and they are characterized by organizational commitment. Also, expectations concerning success are an important factor. In case an employee believes that it can influence the results of the enterprise and that it will directly affect its rewarding system, than individual will become more motivated to engage in the political behavior. If they believe that chance does not affect the outcome, the individual would not waste time and precious resources to influence the change.

A bit different classification of the individual factors of political behavior within the enterprise was given by Robbins (2001). He included the following factors: "self- 
control, internal control locus, lust for power, macchiavelism ${ }^{3}$, contributing into the organization by the members of that organization, the alternative possibilities, inclination towards accepting risks by the members of the organization and the individual value system" (p.366). Namely, people leaning towards self-control are more likely to engage into political behavior, having in mind that they wish their subordinates and resources remain under their control and they also believe that they can affect the impression they leave onto others. Also, the employees possessing lust for power are also more likely to engage into such behavior. Managers and employees with more experience have a lot of business alternatives and they do not want to risk their position, so they are less likely to engage into political behavior in order to advance their careers. Besides that, employees who have aversion towards risk will not be prone to political behavior, having in mind that such behavior includes a certain risk and that they will face the judgement or disapproval of their colleagues. Job satisfaction ${ }^{4}$ can play an important role. The more satisfied an employee is, the less willing they are to take the risk and apply political behavior tactics.

Besides individual factors, the important part in the manifestation of political behavior is also played by the organizational factors. Organizational factors include: "lack of resources, vaguely-specified roles, performance assessment, promotions and democratic decision-making" (Bauer \& Erdogan, 2016). The lack of resources encourages the political behavior within the organization. When resources, as much as the monetary incentives or promotions, become limited, the employees regard their working environment as a political arena. Vaguely-specified roles, in terms of vaguelydefined tasks and positions of the members of the organization, make political behavior imminent within the organization. Research (Muhammad, 2007, p. 234) shows that when responsibilities of the employees are not clearly defined, they lean towards the political behavior more. Ambiguity can occur even when assessment of performance and promotion of the organization members are concerned. Such ambiguities often lead to the showcase of the political behavior within the organization, for example via impression management or information management. Also, democratic decision-making within the organization is an important initiator of political behavior. This happens due to the number of people who are included in the decision making; the more they are the more influencing in various ways employees need.

Uncertainty concerning the business of the enterprise is connected with the organizational factors of political behavior of the employees and managers. Uncertain standards and goals of the enterprise, manipulative and political behavior of the superiors, unclear responsibilities of the employees, unclear possibilities of advancements, high targets and intensive competition with scarce resources represent the most important organizational factors.

Every uncertainty within the organization makes space for the political behavior of the employees. The goal is creating the collegial organizational climate that eliminates the barriers in the communication between the members, as well as distrust and conflicts.

\footnotetext{
${ }^{3}$ For such people is standard to talk to others what the others wish to hear, they usually use the tactic of adulation to their superiors and colleagues and they do not believe other people.

${ }^{4}$ Research shows that the key determinants of job satisfaction can be: salary, the type and quality of training provided by the organization, the scope of work and the employee's ability to express their opinions openly (Zubović, Boškov \& Bešlin Feruh, 2013).
} 
Each individual should have clearly-specified responsibilities and work tasks, should know the desired results and assessment of such results should be based on objective and rational criteria in order to avoid unfair behavior, inequality and favoring which, in the end, results in the decrease of organizational effectiveness and efficiency.

\section{The consequences of political behavior of the employees}

The consequences or effects of the political behavior of the employees within the organization can be positive and negative. Also, such effects can be differed from the aspect of manifestation as well; in other words, individual, affecting the individuals, and organizational, affecting the interests of the organizations in which political behavior is being manifested. For a long period of time the dominating attitude of the researchers in the field of management was that the political behavior was ever more present within the organizations, but that it was also not beneficial for the majority of the organizations, teams and individuals. This is due to the belief that leaning towards accomplishing personal interests creates expenses for the organization as a whole. However, many newer research (Kapoutsis \& Thanos, 2016, p. 310) show that such behavior leads to the increase in productivity, career advancements, larger innovations of the organizations and decision-making via consensus.

"Political behavior refers to deliberate activities which include a wide repertoire, including the tactics of influencing, self-promotion, impression management; or rather, behavior which helps the achievement of desired goals which would otherwise not be possible" (Kapoutsis, 2016, p. 41). Besides that, "political behavior uses the tactics such as impression management, information management, and similar, to secure desired results for the individual, as well as the success at their workplace" (Kimura, 2015). Such definitions of political behavior point out to the usefulness of such behavior of the employees from their career aspects. From this, it can be concluded that the individuals engage in the political behavior in order to fulfill their personal goals which they would not be able to do otherwise, having in mind that the employees manage to gain benefits both in financial and non-material sense. In case the personal goals are in accord with the goals of the enterprise, such behavior by the employees will lead to the organizational interests and vice versa.

Having in mind that the organization is a political environment, it is necessary for the individual to engage in the political behavior for their career success. The studies conducted by Dix and Savickas (1995) imply a strong influence of political skills employees possess on their careers. They have been doing research about the success of the employees at different phases of their careers and they have concluded that making quality contacts with people within the organization, being honest in such relationships, listening to advice and spending time with colleagues outside of the working hours, can have a strong positive influence on the employees' career and such activities are closely related to certain tactics of political behavior. Creating close relationships with the colleagues and especially with the superiors can secure a "privileged treatment".

The individuals with developed political skills who are engaged in the political behavior are at an advantage when compared with other members of the organization 
in terms of getting rewarded and making good quality relationships with the colleagues, superiors, but also with employees on lower hierarchical levels. Such individuals are capable to influence the distribution of the rewards within the organization to their own benefit, by overemphasizing their accomplishments and creating an effective influence toward other members of the organization for their own personal gain (Dix and Savickas, 1995). Political behavior in the organization can influence the increase of the motivation of the employees, their higher production and higher dedication, but only if it is not excessive and illegitimate type of political behavior which has negative outcomes, both for the individual and the organization as a whole. Also, such people have a lot of selfconfidence and they are able to gain the trust of others and to use that in order to achieve their own personal goals or the goals of the organization. They are successful in adapting to the variable environmental conditions, making them the usual choice for leadership roles within the organization.

"The individuals who choose the tactic of the political behavior in correspondence with the situation and use it efficiently, directly influence others through boosting selfconfidence, trust and credibility. Also, politically skilled people are adaptable by nature, which is of the crucial importance for contemporary organizations. The ultimate goal is causing a positive reaction of the person to whom it is intended to influence by using certain tactics of political behavior. This enables positive estimates of the target person in relation to the enhanced reputation of the political behavior "carrier, better performance assessment and having more opportunities for advancement" (Ferris et al., 2007, p. 307). Politically skilled people are capable to self-regulate their behavior in a way that governs the behavior and reactions of others, and they are also skilled in hiding their intentions. Therefore, social wisdom is an important individual characteristic of the employees who are successful in the usage of the political behavior with a goal of career advancement.

Political behavior can help even the employees at lower hierarchical levels, but also the managers holding high positions. On one side, the employees can affect their superiors and to increase their earnings if they manage to make an impression that their personal contribution is higher than their real contribution. Also, they can use this way to draw attention to their results which can otherwise go unnoticed. On the other side, the leaders could spread their influence on their subordinates easier and gain their allegiance. This can ensure the larger individual efficiency and effectiveness, which contributes to the larger organizational efficiency and effectiveness as well. This is especially important in the conditions when organizational changes occur - when the leader needs to convince his subordinates that the changes are good for them. In such environments, the leader needs all the support in order for the changes to succeed.

Some authors (Coopey \& Burgoyne, 2000) point out to the importance of some forms of political behavior for learning within the organization, especially through establishing relationships with more experienced people and making coalitions with subjects both within and outside of the organization, creating positive effects even from the aspect of the individual who acquires new knowledge and new information, but also from the aspect of the organization as well. Such knowledge could be a base of innovation and acquiring the competitive advantage of the company. Such explanation of the consequences of the political behavior of the employees emphasizes the positive side of such tactics, having in mind that by following this method, the relationship based upon trust and reliance is formed, which enables the easier acquirement of knowledge 
and information exchange, which in turn opens a new way of creating knowledge within the organization. Establishing close connections among the colleagues is an important prerequisite of experience exchange and unhindered flow of information within the establishment.

Political behavior is standard for those individuals or groups within the organization who worry about their own interests. "The positive results of such behavior are related to the completion of goals in career, acquiring status and recognition within the organization, power and better position at work, realization of personal goals and completing key tasks. The negative consequences refer to losing of strategic power, reliance and job, losing the higher position, negative feelings towards others, internal feeling of guilt, promotion at insufficient levels and weak performance at work" (Kumar \& Rehana, 1989, p. 306). Both the groups and individuals, in order to achieve their career goals and in order to become promoted to a higher position, use various techniques of political behavior in order to pose competition to other members of the groups or individuals in the organization. The competition is formed by having scarce resources and having limited possibilities of advancement within the enterprise and as competition between members of the organization becomes stronger, engaging in political behavior will be more intense. However, it is of key importance for the individual to evaluate if a certain tactic is justified, in terms of influencing the benefits for the individual because, in some cases, the wish for accomplishment of benefits by using political behavior can have negative effects, for example, in terms of a criticism, judgment and even the loss of job.

Political behavior, in the end, affects the effectiveness of the organization. If the employee manages to gain influence by following this method, this will have repercussions to both individual and group effectiveness. In case the individual refrains from political behavior, in the conditions of extreme competitiveness with scarce resources, that individual will be the victim of that fight. "Having in mind that the organizations are by nature political systems, political behavior is quite normal. Having in mind that the resources of the organization are limited, it is necessary to sacrifice somebody's demands when making decisions for achieving your goals. The members of the organization join the fight as to prevent their part being sacrificed" (Akgemci \& Gok Gokce, 2015, p. 186). It can be deduced that political behavior is sometimes necessary, especially in contemporary methods of doing business.

According to Mintzberg (1977), "positive consequences of the political behavior from the aspect of the organization are: organizational flexibility, introducing organizational changes, getting rewarded according to merit”. In modern business conditions and especially for innovative businesses, organizational flexibility is a prerequisite for successful functioning. This implies flatter organizational structures, flexible employees who are not resisting changes within the company, but regard those changes as means of personal advancement, but also the development of the company. In order to ensure organizational flexibility, the key role is being led by the managers who, using their tactics of political behavior, can influence others to follow and support the changes in the organization. Such behavior from the superiors might influence the subordinate employees to contribute with their own ideas, which would result in the increase of their productivity. A special role here is played by tactics which are used to build trust and credibility of the managers as to make it easier for changes to take roots in the organization. One of the key element of the organizational culture of the successful 
organizations is rewarding by merit. Political behavior can be an important factor for the realization of this system of rewarding the employees, which implies that skillful political managers could objectively assess the results of the members who will achieve their benefits by their merits. In the same manner, political behavior can be a factor of inadequate assessment of the employees' performance, but also some of the best members can leave the organization due to the lack of motivation to engage into political behavior.

Some studies (Sussman et al., 2002) show that political behavior leads to dysfunctional results, such as conflicts, dissatisfaction with the job and decreased productivity. Especially under the conditions of excessive political behavior can some of those events occur; the decline of dedication to the establishment, stress at work, fear of losing the job, bad interpersonal relations, troubled flow of information and knowledge within the organization, the feeling of mistrust and bad environment for the development of the innovative activities. The dedication to the organization decreases due to the lack of motivation by the employees. It has been confirmed by research that older employees are less dedicated to the organization within which excessive political behavior has taken its roots than the younger employees are" (Miller, Rutherford \& Kolodinsky, 2008). One of the reasons can also be the leaning of the younger employees towards advancing in their position in the company by using tactics of political behavior, while the older employees tend to care more for the safe position. An unclear system of performance assessment and rewarding the employees, which is affected by the political behavior of the members of the organization and their various tactics, leads to the decrease of motivation with an increase of the chance that such members would leave the organization after that. This is especially the case with competent employees who are less motivated to engage in political behavior in order to achieve their goals. As a result, the organization can remain without the important human resources, and the biggest problem can be the outflow of important implicit knowledge in the minds of competent employees. Having in mind that the experts are less likely to be motivated with such behavior, there is a risk that they will leave the organization that tolerates excessive political behavior. The loss of their expertise is an important negative consequence of using such tactics.

The organization with a low degree of satisfaction of the employees would hardly achieve their goals (Valle \& Witt, 2001). If there is political behavior within an organization, especially illegitimate which is not sanctified, it will affect the members of the organization by lowering their productivity, the employee satisfaction index, and especially under the influence of increased stress and tension at the workplace. In such conditions, the employees must make a decision whether to engage in the political behavior, use certain defensive mechanisms such as transferring responsibility to another person, excessive conformity, procrastination at work and similar, or leave the organization. Usually other members of the organization resort to this kind of behavior; there is an increase of distrust between the employees, there are conflicts between the members of the organization which in the end results with the decrease of the level of the performance and, with that, the decline in the results of the organization as a whole.

Besides that, some newer researches (Chang, Rosen \& Levy, 2009) of the effects of political behavior from the aspect of the organization members show that individuals react negatively, which might lower their performance, job satisfaction and commitment, with the increase of employee turnover, neglect, absence from work and stress. Stress at work can occur via many different factors, such as high pressure situations, barriers to 
complete tasks and the lack of recognition by managers. The managers play the key role in eliminating the stress that occurs by the excessive use of political behavior within an organization. The environment with poor social relationships between the employees, with a lot of conflict and the lack of support between colleagues is characterizing the presence of extremely stressful situations that distort the working environment (Semmer, 2006).

The individuals who are engaged in political behavior dedicate a lot of attention to this process, having in mind that that process is risky and that failure can easily occur, as well as some negative consequences for the employee. This is the reason they dedicate a lot of their time and energy which can reduce their productivity in the workplace and reduce their commitment to the work assignment. This can affect the reduction of employees' performance, postponement of deadlines and other negative consequences, which ultimately reflect the inability to fulfill the goals of the organization and organizational effectiveness. Although it is possible, political behavior that contributes to the fulfillment of goals of both the individuals and the organization, the use of tactics of political behavior that leads to reduced trust among employees, the creation of fear in the organization, developing a hostile work environment that deteriorates business performance and productivity at the organization level. This creates a barrier in communication, limits the sharing of information and thus reduces organizational efficiency.

Mintzberg (1977) thinks that the key negative consequences of the political behavior within the organization are the unequal distribution of power between the individuals or groups, which leads to inequality, discrimination and the setting of personal goals ahead of organizational interests, which results in inefficiency and time loss on the level of the organization.

According to one research (Olorunleke, 2015, p. 69), political behavior has a negative influence on the fulfillment of the organizational goals. It has been concluded that the organizational performances can be enhanced by liberating the working environment from the political behavior. It is being thought that, this way, the effectiveness and efficiency of completing tasks at work will increase and that the employees would not waste their time on political behavior tactics. The decision-making process is more effective if it is free of political behavior influence, thus emphasizing the direct connection of responsibilities with the initiatives employed managers have. The importance of understanding the employees is being pointed out, for they are the stakeholders of the enterprise and they work for the interest of each and every member of the organization. Also, excessive political behavior in the organization leads to a decline in morale among employees, a greater fluctuation of employees, spending time and effort, which can result in a lower performance of the organization. The managers and leaders play a key role in this environment. They are expected to encourage open and clear communication, to develop the culture of trust between the employees, as well as the team work, avoid any way of making certain individuals seemingly favorite, based only on the factors that are not directly connected with their results, they need to be familiar with the key tactics of political behavior and learn how to recognize such behavior if it occurs within their subordinate employees. It is especially important to ensure the understanding of the organizational goals by every member of the organization and getting agreement with those goals, as well as emphasizing that certain tactics of political behavior are unprofessional and can be sanctioned. The end goal is to prevent the decline of the organizational effectiveness and efficiency. 
Organizations with highly expressive political behavior of their members base the rewarding system on factors such as group memberships or the power of the group members, and not as much on the merits of the individuals (Chang et al., 2012). This creates an unstable working environment and increases insecurities by the employees, which affects them by forcing them to spend more time enhancing their political skills and using the tactics of political behavior, and less time on the realization of the organizational goals.

The political action is of great importance for both the every member of the organization on all levels of hierarchy and for the organization as a whole. Having in mind that such activities influence the effectiveness and efficiency of the organization, the expectations of the individuals and their career goals as well, it can be concluded that politics plays an important role for the organization. If an enterprise cannot manage the political behavior of their members, the negative consequences will occur both from the individual and organizational aspects. Managers must strengthen their attitudes and manage such activities in the organization as to take a preventive reaction for the situations that might occur due to the political behavior of the employees.

\section{Conclusion}

In contemporary organizations, political behavior is bound to happen. The members of the organization are motivated for this behavior so that they could achieve better material and non-material benefits. Such behavior of the employees is not negative only from the aspect of the organization, but the full consequences will depend on the goals and means of such behavior, and on the organizational culture as well. The use of some tactics of political behavior can positively affect the efficiency and effectiveness of the organization and lead to the fulfillment of the organizational goals.

Political behavior involves behavior of social influence that individuals tend to realize their interests which are in accord or against the goals of the organization. In order for someone to achieve career goals by using political behavior, the political skills of that individual are of the biggest importance.

The effects of including the employees into the political behavior can be both positive and negative and they can be observed from the aspect of the individual and from the aspect of the organization as a whole. The most common negative effects of such behavior are connected with the increase of tension and stress at work, the decrease of dedication to the organization, the decline in productivity, the loss of morale, distorting the work atmosphere, limiting communication and exchange of information within the organization, which all contributes to weaker performances on the organizational level. However, we can also talk about certain positive results of the political behavior of the employees. Leaders can use some of those tactics of political behavior to increase motivation of the employees and to boost their effectiveness and efficiency, increase organizational flexibility and make sure that the organizational changes are adapted to quickly.

Political behavior is manifested in the employees on the lower hierarchical levels of the organization as well, in order to boost their position within the organization, but it is the more often the case of higher managerial levels in order to direct their subordinate 
employees. This is the effective way of creating good trusty relationships between the members of the organization, but the excessive use of the tactics of political behavior, especially the illegitimate ones, will have important negative outcomes in the end from the aspect of the organization, and from the aspect of the individual as well. The key role in this process is played by experienced and skillful managers who must be aware of the presence of such activities within the organization and also must find defensive tactics in order to evade the negative consequences of the unavoidable political behavior of the employees.

\section{References}

Akgemci, T., Gökçe Gök, S. L. (2015), The Effects of Politıcal Behavior on the Level of Reachıng Individual Career Goals, International Journal of Business and Social Science, 6 (5), 182-193.

Appelbaum, S. H., Hughes B. (1998), Ingratiation as a Political Tactic: Effects within the Organization, Management Decision, 36 (2), 85-95.

Bauer, T., Erdogan, B. (2016), Organizational Behavior, dostupno na: http://catalog. flatworldknowledge.com/bookhub/3?e=bauer-ch13_s03 (preuzeto 21.09.2016.)

Chang, C. H., Rosen, C. C., Levy, P. E. (2009), The relationship between perceptions of organizational politics and employee attitudes, strain, and behavior: a metaanalytic examination, Academy of Management Journal, 52 (4), 779-801.

Chang, C. H., Rosen, C. C., Siemieniec, G. M., Johnson, R. E. (2012), Perceptions of Organizational Politics and Employee Citizenship Behaviors: Conscientiousness and Self-Monitoring As Moderators, Journal of Business and Psychology, 27 (4), 395-406.

Cheema, I. Q., Cheema, H. A., Ashraf, K. (2008), Leaders' Political Skill, Organizational Politics Savvy, and Change in Organizations - A Constellation, dostupno na : http://www.regent.edu/acad/global/publications/sl_proceedings/2008/cheemaashraf.pdf (preuzeto 17.09.2016.)

Coopey, J., Burgoyne, J. (2000), Politics and Organizational Learning, Journal of Management Studies, 37 (6), 869-885.

Curtis, S. (2003), Lies, damned lies and organizational politics, Industrial and Commercial Training, 35 (7), 293-297.

Dix, J. E., Savickas, M. L. (1995), Establishing a career: Developmental tasks and coping responses, Journal of Vocational Behavior, 47 (1), 93-107.

Farrell, D., Patterson, J. C. (1982), Patterns of political behavior in organizations, Academy of Management Review, 7, 403-412.

Ferris, G. R., Fedor, D. B., King, T. R. (1994), A political conceptualization of managerial behavior, Human Resource Management Review, 4, 1-34.

Ferris, G. R., Perrewé, P. L., Anthony, W. P., Gilmore, D. C. (2000), Political skill at work, Organizational Dynamics, 28, 25-37. 
Ferris, G. R., Treadway, D. C., Kolodinsky, R. W., Hochwarter, W. A., Kacmar, C. J., Douglas, C., Frink, D. D. (2005), Development and validation of the political skill inventory, Journal of Management, 31, 126-152.

Ferris, G. R., Treadway, D. C., Perrewé, P. L., Brouer, R. L., Douglas, C., Lux, S. (2007), Political Skill in Organizations, Journal of Management, 33 (3), 290-320.

Gandz, J., Murray, V. V. (1980), The experience of workplace politics, Academy of Management Journal, 23, 237-251.

Jafariani, H., Mortazavi, S., Nazemi, S. and Bull, P. (2012), Political behavior in organizational context: nature, research and paradigm, Management Science Letters, 2, 2987-3000.

Kapoutsis, I., Thanos, C. I. (2016), Politics in organizations: Positive and negative aspects of political behavior, European Management Journal, 34, 310-312.

Kilduff, M., Day, D. (1994), Do chameleons get ahead? The effects of self-monitoring on managerial careers, Academy of Management Journal, 37, 1047-1060.

Kimura, T. (2015), A review of political skill: current research trend and directions for future research, International Journal of Management Reviews, 17 (3), 312-332.

Kumar, P., Rehana, G. (1989), Organizational Politics and Its Effects on Members of Organizations, Human Relations, 42 (4), 305-314.

Kordić, N., \& Milićević, S. (2018). Human resources in the hotel industry of Serbia. Menadžment u hotelijerstvu i turizmu, 6(1), 93-103.

Latif, A., Abideen, U. Z., Nazar, S. M. (2011), Individual Political Behavior in Organizational Relationship, Journal of Politics and Law, 4 (1), 199-210.

March, J. G. (1962), The Business Firm as a Political Coalition, Journal of Politics, 24, 662-678.

Mayes, B. T., Allen, R. W. (1977), Toward a Definition of Organization Politics, Academy of Management Review, 2, 672-678.

Miles, R. H. (1980), Macro organizational behavior, Santa Monica, Cal.: Goodyear Publishing.

Miller, B. K., Rutherford, M. A., Kolodinsky, R. W. (2008), Perceptions of Organizational Politics: A Meta-Analysis of Outcomes, Journal of Business and Psychology, 22 (3), 209-222.

Mintzberg, H. (1977), Policy as a Field of Management Theory, Academy of Management Review, 2 (1), 88-103.

Muhammad, A. H. (2007), Antecedents of organizational politic perceptions in Kuwait business organizations, Competitiveness Review, 17 (14), 234-247.

Olorunleke, G. K. (2015), Effect of Organizational Politics on Organizational Goals and Objectives, International Journal of Academic Research in Economics and Management Sciences, 4 (3), 59-70.

Perrewe, P. L., Nelson, D. L. (2004), Gender and Career Success: The Facilitative Role of Political Skill, Organizational Dynamics, 33 (4), 366-378.

Robbins, S. P. (2001), Organizational Behavior, Prentice Hall, Inc., New Jersey. 
Semmer, N. K. (2006), Job Stress Interventions and the Organization of Work, Scandinavian Journal of Work, Environment \& Health, 515-527.

Szoc, R. (1999), Power and Political Behavior, dostupno na: http://www.swlearning. com/management/hellriegel/ob10e/isc/web_chapters/00-032C09.pdf (preuzeto 24.09.2016.)

Todd, Y. S., Harris, J. K., Harris, B. R., Wheeler, R. A. (2009), Career Success Implications of Political Skill, The Journal of Social Psycholog, 149 (3), 179-204.

Valle, M., Perrewe, P. L. (2000), Do politics perceptions relate to political behaviours? Tests of an implicit assumption and expanded model, Human Relations, 53 (3), 359-386.

Valle, M., Witt, L. A. (2001), The Moderating Effect of Teamwork Perceptions on the Organizational Politics-Job Satisfaction Relationship, The Journal of Social Psychology, 141 (3), 379-388.

Vigoda-Gadot, E., Drory, A. (2006), Handbook of Organizational Politics: Looking Back and to the future, Cheltenham, UK: Edward Elgar.

Vigoda-Gadot, E., Kapun, D. (2005), Perceptions of politics and perceived performance in public and private organisations: a test of one model across two sectors, Policy \& Politics, 33 (2), 251-276.

Zubović, J., Boškov, V., Bešlin Feruh, M. (2013), Job satisfaction in public sector companies in Vojvodina, Ekonomika, X-XII, No. 4, 32-38. 